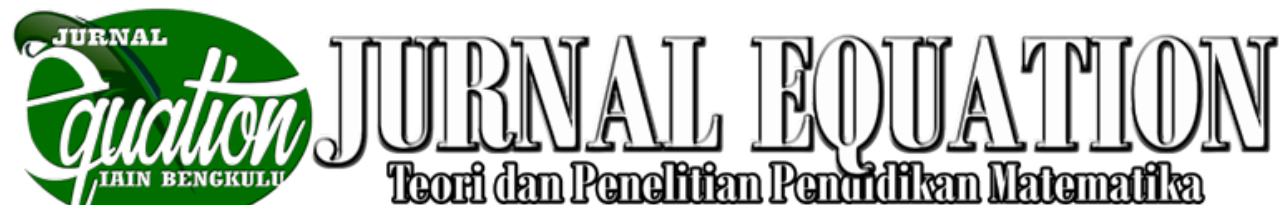

Volume 2 Nomor 2, September 2019, ISSN 2599-3291 (Cetak), ISSN 2614-3933 (Online)

\title{
Muatan Karakter Berdaya Juang Pada Buku Teks Pelajaran Matematika Sma Kelas X Kurikulum 2013
}

\author{
Tria Utari 1) , Hartono ${ }^{2)}$ \\ 1) 2) Prodi Pendidikan Matematika, Program Pascasarjana, Universitas Negeri Yogyakarta. \\ 1)tria.utari.tu@gmail.com, 2hartono@uny.ac.id
}

\begin{abstract}
ABSTRAK
Penelitian ini bertujuan untuk mendeskripsikan muatan karakter berdaya juang pada buku teks matematika SMA kelas X Kurikulum 2013. Penelitian ini menggunakan pendekatan kualitatif deskriptif jenis analisis isi. Sumber data penelitian adalah buku teks Matematika kelas X Kurikulum 2013 edisi revisi 2016 yang diterbitkan oleh Pusat Kurikulum dan Perbukuan Balitbang Kementrian Pendidikan dan Kebudayaan Republik Indonesia. Data penelitian dianalisis menggunakan skema Kripendorff yang meliputi pengumpulan data, penentuan sampel, perekaman/pencatatan, reduksi, penarikan kesimpulan dan narasi. Hasil penelitian menunjukkan bahwa pada bagian non materi pembelajaran ditemukan 5 kalimat yang mengandung motivasi untuk berdaya juang. Pada bagian materi pembelajaran ditemukan 26 masalah. Pada tagihan kerja ditemukan 4 proyek dan latihan yang mengarahkan pada kegiatan pemecahan masalah, diskusi dan tugas kelompok. Pada soal evaluasi ditemukan 36 dari 111 soal yang merupakan masalah matematika. Artinya, buku teks telah memuat masalah, proyek dan soal evaluasi sebagai media untuk mengasah karakter berdaya juang.
\end{abstract}

Kata kunci: analisis isi, karakter berdaya juang, buku teks

\section{ADVERSITY QUOTIENT CONTENTS IN HIGH SCHOOL MATHEMATICS TEXTBOOKS OF 10TH GRADE CURRICULUM 2013}

\begin{abstract}
This study aimed to describe the content of adversity quotient in the high school mathematics textbooks. This research used descriptive qualitative approach type of content analysis. The source of research data was the high school mathematics textbook of 10 th grade Curriculum 2013 edition of revision 2016 published by Ministry of Education and Culture of the Republic of Indonesia. Research data was analyzed using Kripendorff scheme which included unitizing, sampling, recording / coding, reducing, inferring and narrating. The results showed that in the non learning material section found 5 sentences that contain motivation to develope adversity quotient. In the learning material section found 26 problems. On the task section found 4 projects and exercises that lead to problem solving activities, discussions and group assignments. In the evaluation section found 36 of 111 questions which are mathematical problems. That is, the textbook has contained problems, projects and evaluation for developing adversity quotient.
\end{abstract}

Keywords: content analysis, adversity quotient, textbook 


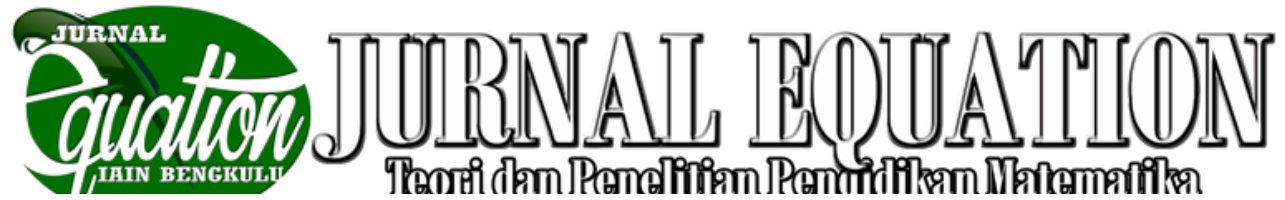

\section{PENDAHULUAN}

Volume 2 Nomor 2, September 2019, ISSN 2599-3291 (Cetak), ISSN 2614-3933 (Online)
Buku merupakan bahan ajar yang sangat berpengaruh dalam proses pembelajaran. Begle menyatakan bahwa "most student learning is directed by the text rather than the teacher" (Thompson, Senk \& Johnson, 2012, p. 254). Artinya, kebanyakan pembelajaran siswa diarahkan oleh buku dibandingkan oleh guru. Buku berfungsi sebagai fasilitator yang mampu membantu siswa belajar mandiri mengembangkan kemampuannya termasuk mengembangkan karakternya. Dalam Permendiknas No 2 Tahun 2008 tentang buku dikatakan bahwa buku teks ialah buku acuan wajib untuk digunakan di satuan pendidikan dasar dan menengah atau perguruan tinggi yang memuat materi pembelajaran dalam rangka peningkatan keimanan, ketakwaan, akhlak mulia, dan kepribadian, penguasaan ilmu pengetahuan dan teknologi, peningkatan kepekaan dan kemampuan estetis, peningkatan kemampuan kinestetis dan kesehatan yang disusun berdasarkan standar nasional pendidikan.

Karakter siswa merupakan hal yang perlu menjadi perhatian dalam dunia pendidikan. Undang-undang Nomor 20 Tahun 2003 tentang Sistem Pendidikan Nasional pada Pasal 3, menyebutkan bahwa pendidikan nasional berfungsi mengembangkan kemampuan dan membentuk karakter serta peradaban bangsa yang bermartabat dalam rangka mencerdaskan kehidupan bangsa.

Terkhusus pada pembelajaran matematika, dijelaskan dalam Permendikbud Tahun 2016 No 21 tentang Standar isi Pendidikan Dasar dan Menengah bahwa kompetensi yang harus dimiliki siswa dalam pembelajaran matematika diantaranya: 1) menunjukkan sikap logis, kritis, analitis, kreatif, cermat dan teliti, jujur, bertanggung jawab, responsif dan tidak mudah menyerah dalam memecahkan masalah; 2) memiliki rasa ingin tahu, percaya diri, semangat belajar yang kontinu, pemikiran reflektif, dan ketertarikan pada matematika, yang terbentuk melalui pengalaman belajar; 3) memiliki rasa percaya pada daya dan kegunaan matematika, serta sikap kritis yang terbentuk melalui pengalaman belajar.

Salah satu kompetensi sikap yang harus dimiliki siswa dalam pembelajaran matematika ialah tidak mudah menyerah. Hal ini berkenaan dengan karakter berdaya juang. Daya juang juga dikenal dengan istilah adversity quotient (AQ). Wardiana, Wiarta dan Zulaikha (2014, p.3) mengungkapkan bahwa dalam konsep kependidikan $A Q$ dikatakan dapat menjadi faktor yang mempengaruhi prestasi belajar siswa, itu dikarenakan $A Q$ merupakan sikap pantang menyerah atau sikap ketahanmalangan. Daya juang tentunya penting dimiliki oleh siswa agar mereka mampu menghadapi berbagai masalah dan tantangan 
Volume 2 Nomor 2, September 2019, ISSN 2599-3291 (Cetak), ISSN 2614-3933 (Online)

baik dalam pelajaran di sekolah maupun di masyarakat.

Pada kenyataannya, siswa di Indonesia belum memiliki karakter berdaya juang yang tinggi. Hasil survei awal peniliti di SMA Negeri 1 Depok dengan sampel 29 orang siswa kelas $X$ menunjukkan bahwa daya juang siswa baru mencapai kategori sedang. Hasil survey menunjukkan bahwa $90 \%$ siswa masih tergolong dalam kategori berdaya juang sedang. Artinya, perlu ada upaya untuk meningkatkan daya juang tersebut. Hal ini jelas tidak memenuhi kompetensi yang diharapkan dari pembelajaran matematika, yakni tidak mudah menyerah dalam menyelesaikan masalah.

Begitu pentingnya karakter ditumbuhkan dalam diri siswa, sehingga muatan karakter penting untuk diterapkan dalam buku teks pelajaran. Pada Permendiknas No 2 Tahun 2008 Pasal 1d ikemukakan bahwa buku teks memuat pembelajaran salah satunya dalam rangka pembentukan kepribadian. Buku teks menjadi sumber bagi siswa untuk memperoleh ilmu pengetahuan dan nilai-nilai yang akan mempengaruhi pembentukan karakternya. Secara khusus, karakter berdaya juang penting untuk dimuat dalam buku teks agar dapat membantu siswa menjadi seorang yang tangguh dan tidak mudah menyerah. Artinya, di dalam buku teks diharapkan terdapat muatan yang secara eksplisit maupun implisit dapat membentuk karakter berdaya juang dalam diri siswa.

Saat ini, buku teks pelajaran di Indonesia sudah memuat nilai-nilai pendidikan karakter. Sebagaimana penelitian yang dilakukan oleh Asih Putri Utami menunjukkan bahwa nilai-nilai pendidikan karakter sudah terintegrasi dalam buku siswa Kurikulum 2013 mata pelajaran bahasa Indonesia SMP kelas VII dan SMA kelas X. Penelitian Asih Putri Utami merupakan salah satu contoh penelitian analisis muatan karakter secara umum pada buku. Sedangkan, belum ada analisis buku yang secara khusus memperhatikan muatan karakter berdaya juang. Oleh karena itu, penting untuk melakukan analisis muatan karakter berdaya juang pada buku teks, khususnya matematika.

Karakter berdaya juang merupakan terjemahan dari istilah adversity quotient. Stoltz (1997) mengungkapkan bahwa adversity quotient merupakan pengetahuan baru, tolak ukur dan peralatan untuk mengetahui dan memperbaiki respons seseorang terhadap kesulitan. Devakumar (2012) mendefinisikan adversity quotient sebagai ilmu kekebalan hidup, dimana ilmu kekebalan ialah kemampuan untuk beradaptasi dengan baik terhadap stress, kesulitan, trauma atau tragedi. Parvaty dan Praseeda (2014, p.23) mendefinisikan adversity quotient sebagai kemampuan untuk berurusan dengan kesulitan dalam hidupnya. Menurut Phoolka dan Kaur

Tria Utari, Hartono Muatan Karakter... 


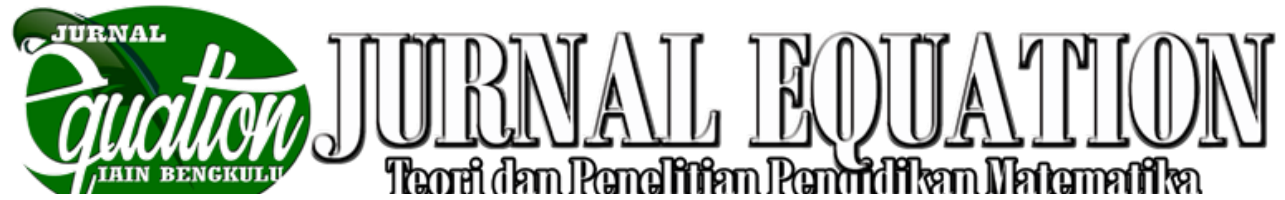

Volume 2 Nomor 2, September 2019, ISSN 2599-3291 (Cetak), ISSN 2614-3933 (Online)

(2012) adversity quotient merupakan hal yang dapat menjelaskan seberapa baik seseorang dapat bertahan dalam kesulitan dan kemampuannya untuk mengatasinya. Tigchelaar dan Bekhet (2015, p.403) mendefinisikan adversity quotient sebagai kapasitas seseorang dalam berurusan dan merespon kesulitan dalam hidup.

Zainuddin (2012, p.3) mengungkapkan bahwa adversity quotient adalah kemampuan seseorang untuk dapat bertahan menghadapi kesulitan-kesulitan dan mampu mengatasi tantangan hidup. Sudarman (2012, p.55) mendefinisikan adversity quotient sebagai kecerdasan dalam mengatasi kesulitan. Napitapulu dan Nashori (2006, p.47) mengungkapkan bahwa adversity quotient merupakan kemampuan seseorang dalam menggunakan kecerdasannya untuk mengarahkan, mengubah cara berpikir dan tindakannya ketika menghadapi hambatan dan kesulitan yang bisa menyengsarakan dirinya. Bahasa yang paling berbeda dikemukakan oleh Maureen (2015,p.10) yang menyatakan bahwa adversity quotient merupakan sebuah ilmu, teori, dan pendekatan yang mapan untukEmpat aspek ini lebih dikenal dengan $\mathrm{CO}_{2} \mathrm{RE}$ yang menjadi lebih tangguh secara terukur. Definisidefinisi di atas mengarahkan pada pemahaman bahwa adversity quotient merupakan kemampuan seseorang dalam merespon kesulitan yang dihadapi. Adversity quotient dapat menjelaskan bagaimana seseorang dapat bertahan dan mengatasi kesulitan yang ada.

Stoltz (1997) mengungkapkan bahwa daya juang seseorang dapat dinilai dari beberapa aspek, yakni:

a. Kontrol (control): "How much control do you perceive that you have over an adverse event?" Seseorang mampu mengendalikan masalah/kesulitan.

b. Asal usul dan pengakuan (origin and ownership): "Who or what was the origin of the adversity? And to what degree do I own the outcomes of the adversity?" Seseorang mampu mengakui kekurangan/kesalahan dan bertanggung jawab untuk memperbaiki.

c. Jangkauan (reach): "How far will the adversity reach into other areas of my life?" Seseorang mampu membatasi kesulitan yang ada dan tidak membesar-besarkan masalah.

d. Daya tahan (endurance): "How long will the adversity last? And how long will the cause of the adversity last?" Seseorang mampu meyakinkan dirinya bahwa kesulitan yang dihadapinya tidak akan abadi dan suatu saat pasti bisa diatasi.

kemudian banyak digunakan dalam penelitian untuk mengukur daya juang seseorang.

Daya juang erat kaitannya dengan motivasi. Amir dan Risnawati (2016, p.179) berpendapat bahwa daya juang siswa akan berjalan seiring dengan motivasi yang 
Volume 2 Nomor 2, September 2019, ISSN 2599-3291 (Cetak), ISSN 2614-3933 (Online)

didapatkannya. Bukhari, Saeed, dan Nisar (2011, p. 8395) mengungkapkan bahwa orang yang memiliki daya juang yang tinggi akan termotivasi, produktif dan memiliki perhatian terhadap atrisi yang lebih rendah. Hasil penelitian Cornista dan Macasaet (2013, p.2) menunjukkan bahwa terdapat hubungan antara daya juang dengan motivasi untuk berprestasi. Santrock (2009, p.243) menyatakan bahwa motivasi merupakan proses yang memberikan energi, mengarahkan dan mempertahankan perilaku. Motivasi belajar berprestasi ialah berbagai aktivitas yang dilakukan untuk menimbulkan dorongan, membangkitkan, mengelola, mempertahankan dan menyalurkan tingkah laku menuju prestasi (Amir \& Risnawati, 2016, p.178). Kalimat motivasi untuk berdaya juang akan sangat relevan dimuat dalam buku teks untuk meningkatkan daya juang siswa.

Menurut Rifameutia (Hawadi, 2004, p.199) pengembangan adversity quotient dapat dicapai melalui pendekatan pembelajaran yang memungkinkan siswa untuk menerapkan langkah-langkah pemecahan masalah dan berkomunikasi secara aktif melalui kegiatan belajar mandiri maupun berkelompok yang memuat tugas-tugas belajar yang menantang dan siswa mengambil peran yang lebih besar dalam tanggung jawab belajarnya.Hal ini menjadi isyarat bahwa buku teks perlu memuat sajian materi dan tagihan kerja yang memberikan kesempatan kepada siswa untuk melakukan kegiatan pemecahan masalah dalam rangka mengasa daya juang.

Amir dan Risnawati menjelaskan bahwa salah satu ciri rendahnya daya juang siswa ialah pasif dan apatis serta mencari posisi aman untuk terhindar dari ancaman. Artinya perlu suatu upaya agar siswa menjadi aktif dan berani keluar dari zona aman. Upaya ini salah satunya ialah dengan melibatkan mereka dalam tagihan kerja. Sekali lagi ini menjadi alasan mengapa buku teks perlu memuat tagihan kerja yang memberikan kesempatan kepada siswa untuk melakukan kegiatan dalam rangka mengasa daya juang.

Untuk mengasa daya juang hendaknya siswa dihadapkan dengan kesulitan. Kesulitan yang nyata dalam pembelajaran matematika yang dapat dimuat dalam buku ialah masalah matematika.Burns (2007) menyebutkan kriteria masalah yaitu (1) There is a perplexing situation that the student understands

(2) The student is interested in finding a solution (3) The student is unable to proceed directly toward a solution (4) The solution requires use of mathematical ideas .Pada poin kedua, dapat dipahami bahwa masalah matematika haruslah menarik. Menurut Savizy (2007) 


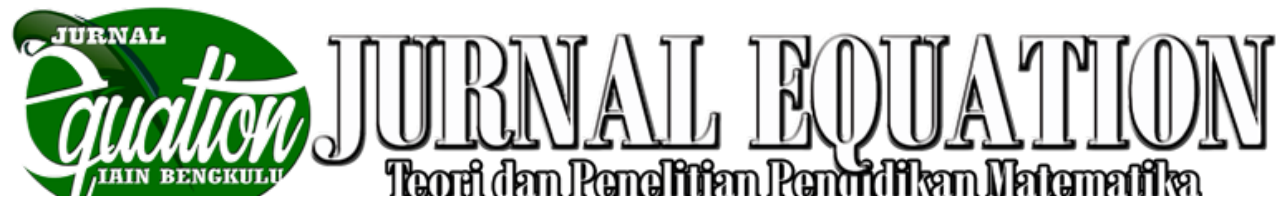

masalah yang menarik disajikan adalah

\section{Sumber Data}

masalah yang berasal dari kehidupan nyata,

Data pada penilitian ini diambil dengan karena masalah ini membawa kehidupan ke konsep abstrak matematika yang mereka pelajari, dan membuat konsep yang lebih nyata.

Berdasarkan latar belakang berikut kajian teorinya, maka rumusan masalah yang digunakan dalam penelitian ini adalah bagaimana muatan karakter berdaya juang pada buku teks matematika SMA kelas $X$ Kurikulum 2013? Adapun tujuan penelitian ini adalah mendeskripsikan muatan karakter berdaya juang pada buku teks matematika SMA kelas X Kurikulum 2013.

\section{METODE PENELITIAN}

Jenis Penelitian

Penelitian ini menggunakan pendekatan kualitatif dengan analisis konten. Penelitian ini bertujuan memahami muatan karakter berdaya juang. Dokumen yang dianalisis adalah buku teks Pelajaran Matematika SMA Kelas X Kurikulum 2013 edisi revisi 2016 yang diterbitkan oleh Pusat Kurikulum dan Perbukuan Balitbang Kementrian Pendidikan dan Kebudayaan Republik Indonesia.

\section{Setting Penelitian}

Penelitian ini merupakan penelitian analisis konten yang sumber data penelitiannya berupa dokumen sehingga dalam pengkajiannya tidak dibatasi oleh lokasi tertentu. meniliti subjek dan objek penelitian. Subjek penelitian ini berupa dokumen yang dianalisis, yakni buku teks Pelajaran Matematika SMA Kelas X Kurikulum 2013 Edisi Revisi 2016 yang diterbitkan oleh Pusat Kurikulum dan Perbukuan Balitbang Kementrian Pendidikan dan Kebudayaan Republik Indonesia pada tahun 2016. Pemilihan buku tersebut sebagai subjek penelitian didasarkan pada standar kelayakan oleh BSNP yang menyatakan bahwa buku induk yang dipakai untuk siswa SMA kelas $X$ adalah buku yang diterbitkan oleh Pusat Kurikulum dan Perbukuan Balitbang Kemdikbud. Objek penelitian yang digunakan adalah muatan karakter berdaya juang.

\section{Teknik dan Isntrumen Pengumpulan Data}

Teknik pengumpulan data dalam penelitian ini adalah pembacaan dan pencatatan yang cermat terhadap buku teks. Instrumen utama yang digunakan dalam penelitan ini adalah human instrument yaitu peneliti sendiri. Pengetahuan, ketelitian, dan kekritisan peneliti dalam mencari dan menggali untuk menemukan data-data yang diperlukan sesuai dengan permasalahan penelitian. Peneliti menggunakan instrumen tabel data, untuk memudahkan proses kategorisasi data. Instrumen yang digunakan dalam penelitian ini adalah pedoman analisis dan lembar analisis 
Volume 2 Nomor 2, September 2019, ISSN 2599-3291 (Cetak), ISSN 2614-3933 (Online)

dokumen yang disusun berdasarkan landasan teori tentang muatan karakter berdaya juang.

Muatan karakter berdaya juang dalam penelitian ini ialah bagian non materi pembelajaran, bagian materi pembelajaran, tagihan kerja dan soal evaluasi yang memfasilitasi siswa dalam mengembangkan karakter berdaya juang.

Tabel 1. Kisi-kisi Instrumen Analisis Muatan Karakter Berdaya Juang

\begin{tabular}{|c|l|l|}
\hline $\mathrm{N}$ & Aspek & \multicolumn{2}{|l|}{ Indikator } \\
\hline 1 & $\begin{array}{l}\text { Non Materi } \\
\text { Pembelajaran }\end{array}$ & $\begin{array}{l}\text { Memuat kalimat motivasi } \\
\text { untuk berdaya juang } \\
\text { secara eksplisit }\end{array}$ \\
\hline 2 & $\begin{array}{l}\text { Materi } \\
\text { Pembelajaran }\end{array}$ & $\begin{array}{l}\text { Memuat masalah } \\
\text { pemecahan } \\
\text { yang memfasilitasi siswa } \\
\text { untuk mengasah daya } \\
\text { juang }\end{array}$ \\
\hline 3 & Tagihan Kerja & $\begin{array}{l}\text { Memuat tugas } \\
\text { pemecahan masalah baik } \\
\text { secara mandiri maupun } \\
\text { berkelompok }\end{array}$ \\
\hline 4 & Soal Evaluasi & $\begin{array}{l}\text { Memuat masalah } \\
\text { matematika }\end{array}$ \\
\hline
\end{tabular}

Bagian non materi pembelajaran terdiri atas kata pengantar, pengantar sebelum masuk ke dalam penyajian materi dan, penutup setelah penyajian materi. Materi pembelajaran ialah konten yang terdapat dalam bagian "Materi Pembelajaran" pada buku kecuali paragraf pengantar dan penutup. Tagihan kerja dalam buku yang diteliti ialah proyek dan latihan. Soal evaluasi dalam buku yang diteliti ialah soal-soal yang terdapat pada uji kompentensi.

\section{Keabsahan Dokumen}

Keabsahan data dalam penelitian ini didasarkan pada validitas dan reliabilitas. Validitas yang digunakan dalam penelitian ini adalah validitas semantik (semantic validity), yaitu validitas yang mengetengahkan sejauh mana kategori dari analisis teks sesuai dengan makna teks-teks ini dalam konteks yang dipilih (Kripendorff, 2004, p.323). Validitas semantik dibuktikan dengan cara melihat kesesuaian data dan dimaknai sesuai konsepnya oleh ahli. Validasi instrumen dan data dilakukan dengan pengecekan/pemeriksaan oleh ahli (expert judgement). Expert judgement instrumen pada penelitian ini dilakukan oleh dua orang ahli.

Reliabilitas yang digunakan dalam penilitian ini adalah stabilitas (stability) dan reproduktabilitas (reproducibility). Reliabilitas stabilitas dilakukan dengan cara mencermati kembali sumber data yang tersedia secara berulang-ulang untuk mendapatkan pemahaman yang konsisten terhadap data yang berhubungan dengan aspek yang diteliti (Kripendorff, 2004, p.215) proses tidak berubah dari waktu ke waktu. Reliabilitas stabilitas disebut sebagai intracoder reability, karena data yang dibandingkan adalah data dari coder yang sama (Eriyanto, 2011, p.285). Pada 
Volume 2 Nomor 2, September 2019, ISSN 2599-3291 (Cetak), ISSN 2614-3933 (Online)

penelitian ini, pencermatan sumber dilakukan peneliti sebanyak 4 kali.

Reliabilitas reproduktabilitas dilakukan dengan cara diskusi dan konfirmasi dengan teman sejawat, yaitu dua atau lebih individu, bekerja independen satu sama lain, menerapkan instruksi recording yang sama dengan unit yang sama dari analisis (Kripendorff, 2004, p.215). Reliabilitas reproduktabilitas disebut dengan intercoder reability atau interater (Eriyanto, 2011, p.286)

\section{Teknik Analisis Data}

Teknik analisis data yang digunakan pada penelitian ini adalah skema analisis isi menurut Kripendorff (2004, p.83). Terdapat enam tahapan dalam skema analisis tersebut, yakni Unitizing (Pengumpulan Data), Sampling (Penentuan sampel), Recording/coding (Perekaman/ Pencatatan), Reducing (Reduksi), Inferring (Penarikan Kesimpulan) dan Narrating (Penarasian).

Pada tahap pengumpulan data, yang dimaksud unit adalah membedakan sistematis data yang dianalisis sesuai dengan pertanyaan penelitian yang telah dibuat. Kegiatan unitizing dalam penelitian ini dilakukan dengan menentukan tiga jenis unit, yakni sampling units, recording units dan context unit. Sampling units merupakan unit yang dibedakan untuk pencantuman eksklusif dalam suatu analisis (Kripendorff, 2004, p.98). Sampling units dalam penelitian ini ialah buku teks
Pelajaran Matematika SMA Kelas X Kurikulum 2013. Recording units merupakan unit yang dibedakan untuk memisahkan deskripsi, transkripsi, pencatatan atau pengkodean (Kripendorff, 2004, p.99). Recording units dalam penelitian ini adalah non materi pembelajaran, materi pembelajaran, tagihan kerja dan soal evauasi. Context unit merupakan unit terkait hal tekstual yang mengatur batasan informasi yang dipertimbangkan dalam pendeskripsian recording units (Kripendorff, 2004, p.101). Context unit dalam penelitian ini ialah muatan karakter berdaya juang.

Penentuan sampel adalah proses penyederhanaan penelitian dengan membatasinya pada observasi yang merupakan bagian semua jenis unit sehingga terkumpul unit-unit dengan tema/karakter yang serupa. Penentuan sampel pada penelitian ini dilakukan dengan metode purposive sampling, yakni peneliti secara sengaja memilih sampel atau periode tertentu atas dasar pertimbangan ilmiah (Eriyanto, 2011, p.147). Setelah sampel ditentukan, penelitian dilanjutkan dengan pencatatan dan deskripsi terhadap konten buku yang berkaitan dengan muatan karakter berdaya juang. Pencatatan dilakukan dengan mengutip bagian dalam buku yang sesuai dengan indikator yang telah dibuat sebelumnya dan mentabulasi ke dalam lembar analisis.

Catatan dan deskripsi yang dihasilkan dari tahapan sebelumnya kemudian direduksi. 
Volume 2 Nomor 2, September 2019, ISSN 2599-3291 (Cetak), ISSN 2614-3933 (Online)

Reduksi data pada penelitian ini dilakukan selama tahap analisis data. Reduksi dilakukan lebih kepada penyusunan secara sistematis untuk memunculkan pola dan dikaitkan dengan menyesuaikan aspek-aspek yang tercantum pada pertanyaan penelitian.

Penarikan kesimpulan dilakukan dengan menganalisa data lebih dalam dengan mencari makna data. Penyimpulan menjembatani data deskriptif dengan pemaknaan. Penyimpulan dilakukan dengan berdasarkan konstruk analisis yang ada. Konstruksi analitis yang digunakan adalah representasi, yang biasa digunakan dalam analisis wacana. Penelitian ini menggunakan representasi sesuai analisis buku teks, yaitu dengan memetakan hasil reduksi untuk memperoleh jawaban atas pertanyaan untuk disimpulkan.

Tahap akhir dari penelitian ini ialah membuat narasi. Narasi merupakan deskripsi yang berisi jawaban pertanyaan penelitian. Narasi juga berisi informasi-informsi penting. Informasi ini bertujuan memaparkan data hasil penelitian sesuai dengan teori. Deskripsi dilakukan dengan mengkaji hasil analisis dengan sumber-sumber yang sesuai.

\section{HASIL DAN PEMBAHASAN}

Berdasarkan hasil analisis muatan karakter berdaya juang pada buku teks, maka didapatkan beberapa temuan yang dirangkum dalam tabel di bawah ini.

Tabel 2. Temuan Berdasarkan Hasil

Analisis Muatan Karakter Berdaya Juang

\begin{tabular}{|c|c|c|c|c|c|c|}
\hline $\begin{array}{l}\text { agian } \\
\text { Buku } \\
\text { spek }\end{array}$ & $\begin{array}{l}\text { ata } \\
\text { Pen } \\
\text { gant } \\
\text { ar }\end{array}$ & $\begin{array}{l}\quad \text { Pers } \\
\text { amaan dan } \\
\text { Pertidaksam } \\
\text { aan Nilai } \\
\text { Mutlak } \\
\text { Linear Satu } \\
\text { Variabel }\end{array}$ & $\begin{array}{l}\text { istem } \\
\text { Persa } \\
\text { maan } \\
\text { Linear } \\
\text { Tiga } \\
\text { Variab } \\
\text { el }\end{array}$ & $\begin{array}{l}\text { un } \\
\text { gs } \\
\text { i }\end{array}$ & $\begin{array}{l}\text { rigo } \\
\text { nom } \\
\text { etri }\end{array}$ & otal \\
\hline $\begin{array}{l}\text { agian } \\
\text { non } \\
\text { materi }\end{array}$ & & 1 & & & & \\
\hline $\begin{array}{l}\text { ateri } \\
\text { Pemb } \\
\text { elajar } \\
\text { an }\end{array}$ & & 5 & & & 3 & 6 \\
\hline $\begin{array}{l}\text { agiha } \\
\mathrm{n} \\
\text { Kerja }\end{array}$ & & 1 & & & & \\
\hline $\begin{array}{l}\text { oal } \\
\text { Evalu } \\
\text { asi }\end{array}$ & & 6 & & 0 & 4 & 6 \\
\hline
\end{tabular}

Berdasarkan Tabel 2 terlihat bahwa temuan muatan karekter berdaya juang pada buku beragam sesuai dengan aspek yang diamati. Angka temuan pada aspek kalimat pada wacana non materi dan tagihan kerja jauh lebih kecil dibandingkan aspek wacana/ penjelasan materi dan soal evaluasi dikarenakan proporsi wacana non materi dan tagihan kerja pada buku memang hanya sedikit.

1) Muatan Karakter Berdaya Juang pada Bagian Non Materi

Dari keseluruhan buku, didapatkan lima temuan yang menunjukkan nilai karakter Tria Utari, Hartono Muatan Karakter... 


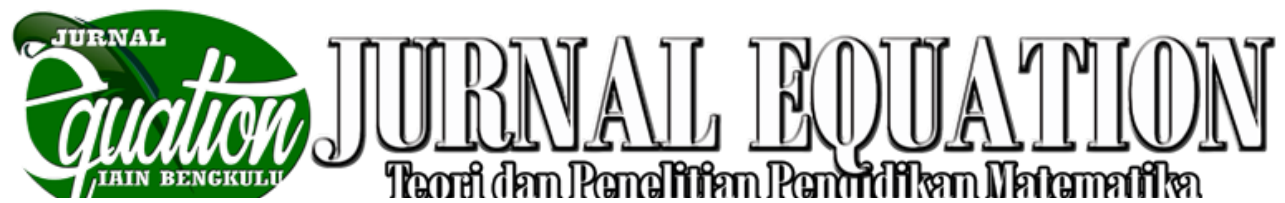

Volume 2 Nomor 2, September 2019, ISSN 2599-3291 (Cetak), ISSN 2614-3933 (Online)

berdaya juang. Pada halaman iii ditemukan

satu kalimat yang memuat nilai karakter berdaya juang.

Matematika adalah hasil abstraksi (pemi objek di sekitar kita dan menyelesaikan masala sehingga dalam mempelajarinya Kamu $\mathrm{h}$ bagaimana pemikiran para penciptanya terda berguna bagi kehidupan. Cobalah membac terapkan untuk menyelesaikan masalah-masa. Kamu punya kemampuan, kami yakin kamu ]

Gambar 1. Temuan Kalimat Bernilai

Daya Juang Aspek Kontrol

Kalimat "kamu punya kemampuan, kami yakin kamu pasti bisa melakukannya" menunjukkan nilai karakter berdaya juang khususnya aspek "kontrol" dan aspek "daya tahan" . Pada aspek "kontrol" seseorang dinilai tingkat daya juangnya dengan melihat apakah ia mampu mengendalikan kesulitan/ masalah. Pada aspek "daya tahan" seseorang dinilai tingkat daya juangnya dengan melihat apakah ia mampu meyakinkan dirinya bahwa kesulitan yang dihadapinya tidak akan abadi dan suatu saat pasti bisa diatasi. Pada kalimat "kamu punya kemampuan, kami yakin kamu pasti bisa melakukannya" siswa diyakinkan memiliki kemampuan untuk mengatasi kesulitan/ masalah.

Lima temuan yang diperoleh secara keseluruhan termuat secara eksplisit dalam kalimat yang ada. Temuan ini sekaligus menegaskan bahwa buku ini potensial bagi siswa untuk mengembangkan daya juang melalui pemecahan masalah. Kalimat dengan Tria Utari, Hartono Muatan Karakter... muatan karakter berdaya juang hanya didapatkan pada bagian kata pengantar, rangkuman materi Persaman dan Pertidaksamaan Linear Harga Mutlak Satu Variabel dan pada bagian pengantar materi Sistem Persamaan Linear Tiga Variabel. Sementara, pada materi Fungsi dan Trigonometri, kalimat tersebut tidak ditemukan sama sekali.

Meski secara eksplisit tidak ditemukan kata "daya juang", namun secara implisit kalimat yang tercantum merupakan motivasi untuk memecahkan masalah dengan kata lain ialah daya juang. Selain berisi motivasi, temuan ini juga menjelaskan bahwa buku teks Pelajaran Matematika SMA Kelas X Kurikulum 2013 Edisi Revisi 2016 yang diterbitkan oleh Pusat Kurikulum dan Perbukuan Balitbang Kementrian Pendidikan dan Kebudayaan Republik Indonesia berisi materi yang memfasilitasi siswa untuk mengasah daya juang. Artinya, dengan membaca buku dengan seksama, siswa bisa mendapatkan motivasi untuk berdaya juang. Kalimat motivasi dalam buku ini sangat sedikit dikarenakan porsi wacana non materi yang sedikit.

2) Muatan Karakter Berdaya Juang pada Materi Pembelajaran

Dalam prakteknya untuk melatih siswa memiliki karakter berdaya juang, yakni mampu menghadapi masalah, siswa hendaknya dibiasakan dihadapkan dengan masalah. Hal ini 


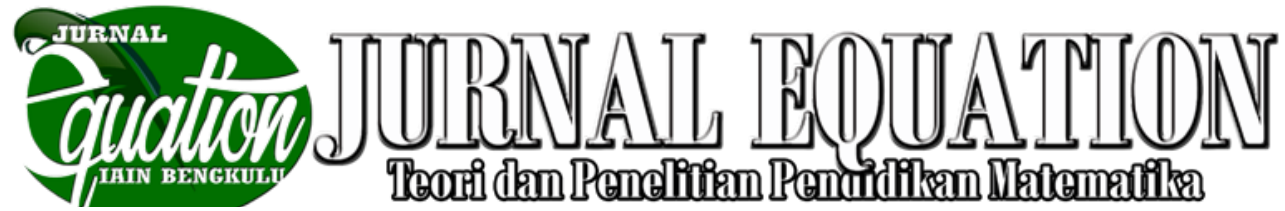

Volume 2 Nomor 2, September 2019, ISSN 2599-3291 (Cetak), ISSN 2614-3933 (Online)

yang melandaskan analisis muatan karakter berdaya juang dalam wacana/ penjelasan materi dengan meihat muatan masalah yang disajkan dalam wacana/ penjelasan materi tersebut sebagai media pengembangan karakter berdaya juang.

Dari keseluruhan buku didapatkan 26 temuan wacana / penjelasan materi yang memuat masalah untuk dipecahkan oleh siswa. Pada materi Persamaan dan Pertidaksamaan Nilai Mutlak Linear Satu Variabel ditemukan lima masalah yang diasjikan dalam wacana/ penjelasan materi. Masalah ini kemudian menjadi media bagi siswa untuk berlatih mengatasi masalah. Adapun temuan yang didapatkan antara lain Masalah 1.1, Masalah 1.2, Masalah 1.3, Masalah 1.4 dan Masalah 1.5 .

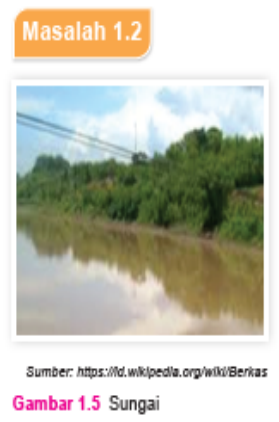

Perhatikan Gambar 1.5 di sungai in Sungai pada keadaan tertentu mempunya sifat cepat meluap di musim hujan dan cepe kering di musim kemarau. Diketahui debit ai sungai tersebut adalah $p$ liter/detik pada cuac normal dan mengalami perubahan deb: sebesar $q$ liter/detik di cuaca tidak normal. Tunjukkan nilai penurunan minimur dan peningkatan maksimum debit air sunge tersebut.

Gambar 2. Masalah 1.2 pada Halaman 10-11

Masalah 1.2 merupakan masalah otentik. Dengan demikian, masalah ini potensial bagi siswa baik untuk melatih daya juangnya. Dalam menyelesaikan masalah matematika maupun menyelesaiakan masalah di kehidupan nyata. Penyelesaian masalah ini telah disediakan di buku.

Secara keseluruhan, masalah yang ditemukan telah memiliki alternatif penyelesaian yang telah disajikan dalam buku. Maka, sesuai dengan petunjuk kegiatan pembelajaran pada buku guru, proses pembelajaran harus disesuaikan agar memberikan kesempatan bagi siswa untuk melatih daya juang, yakni dengan meminta siswa untuk menyelesaikan masalah tersebut terlebih dahulu tanpa melihat alternatif penyelesaiannya. Masalah yang disajikan dalam wacana/ penjelasan materi merupakan masalah otentik dan non otentik. Artinya, hal ini meberikan kesempatan kepada siswa untuk melatih daya juang dalam menyelesaikan masalah matematika dan dalam kehidupan nyata. Adapun keterangan bahwa penyelesaian masalah ini merupakan kegiatan yang harus dilakukan siswa, tercantum dalam buku guru Pelajaran Matematika SMA Kelas X Kurikulum 2013 Edisi Revisi 2016 yang diterbitkan oleh Pusat Kurikulum dan Perbukuan Balitbang Kementrian Pendidikan dan Kebudayaan Republik Indonesia.

3) Muatan Karakter Berdaya Juang pada Tagihan Kerja

Analisis muatan kesulitan pada tagihan kerja berfokus pada tagihan kerja yang mengarahkan siswa untuk aktif (baik secara mandiri maupun berkelompok) dan keluar dari zona aman. Setelah dianalisis, pada buku Tria Utari, Hartono Muatan Karakter... 


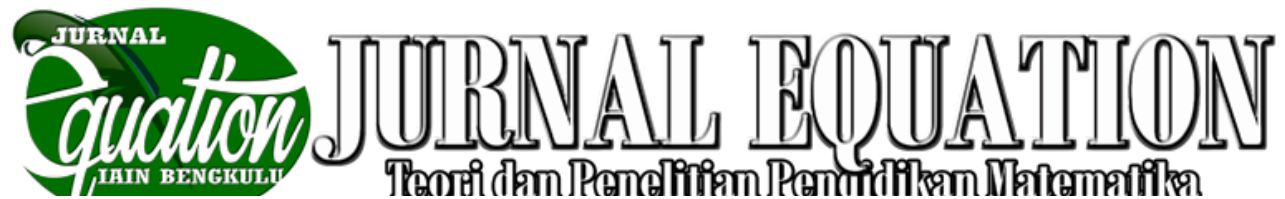

Volume 2 Nomor 2, September 2019, ISSN 2599-3291 (Cetak), ISSN 2614-3933 (Online)

ditemukan empat tagihan kerja yang memenuhi

kriteria tersebut, yakni Latihan 1.4 pada halaman 26, Proyek pada halaman 49, Proyek pada halaman 102 dan Proyek pada halaman 195.

\section{Proyek}

Cari sebuah SPLTV yang menyatakan model matematika dari mas nyata yang kamu temui di lingkungan sekitarmu. Uraikan proses penem model matematika tersebut dan selesaikan sebagai pemecahan mas tersebut. Buat laporan hasil kerjamu dan hasilnya dipresentasikan di de kelas.

Gambar 3. Proyek pada Halaman 49

Proyek ini terdapat pada materi Sistem Persamaan Linear Tiga Variabel. Proyek ini potensial bagi siswa untuk melatih daya juang dalam menyelesaikan masalah dalam kehidupan nyata. Berdasarkan buku guru pada halaman 55, proyek ini merupakan tugas kelompok. Artinya, hal ini potensial melatih daya juang melalui interaksi sosial. Artinya, siswa tidak hanya berlatih mengatasai masalah sendirian namun bersama dengan temantemannya.

\section{4) Muatan Karakter Berdaya} Juang pada Soal Evaluasi

Analisis muatan karakter berdaya juang pada soal evaluasi dilakukan dengan mengidentifikasi soal yang terdefinisi sebagai masalah. Artinya, soal tersebut memberi kesempatan bagi siswa untuk melatih daya juang dalam menyelesaikan masalah matematika. Secara keseluruhan, teridentifikasi
36 dari 111 soal pada uji kompetensi yang merupakan masalah matematika.

Pada materi Persamaan dan Pertidaksamaan Nilai Mutlak Linear Satu Variabel teridentifikasi 6 masalah, yakni Uji Kompetensi 1.1. nomor 2 dan 6 serta Uji Kompetensi 1.2 nomor 1, 3, 8, dan 10.

8. Berdasarkan definisi atau sifat, buktikan $|a-b| \leq|a+b|$

Gambar 4. Uji Kompetensi 1.2 Nomor 8

Soal nomor 8 pada Uji Kompetensi 1.2 merupakan salah satu contoh soal pada materi Persamaan dan Pertidaksamaan Nilai Mutlak Linear Satu Variabel yang merupakan masalah matematika. Soal ini diidentifikasi sebagai masalah matematika karena dalam penyelesaiannya tidak cukup dengan prosedur rutin. Siswa perlu menggunakan definisi nilai mutlak untuk menyelesaikan soal tersebut.

Masalah-masalah matematika yang ditemukan pada soal-soal evaluasi berupa Uji Kompetensi pada buku SMA Kelas X Kurikulum 2013 Edisi Revisi 2016 yang diterbitkan oleh Pusat Kurikulum dan Perbukuan Balitbang Kementrian Pendidikan dan Kebudayaan Republik Indonesia dinilai bermuatan karakter berdaya juang karena potensial bagi siswa untuk melatih daya juang siswa. Analisis muatan karakter berdaya juang pada soal evaluasi dilakukan dengan cara mengidentifikasi soal yang masuk kategori masalah matematis diantara seluruh soal evaluasi yang ada. Dengan melihat porsi 
Volume 2 Nomor 2, September 2019, ISSN 2599-3291 (Cetak), ISSN 2614-3933 (Online)

masalah matematika dalam soal evaluasi, kita dapat melihat kesempatan siswa untuk mengasah daya juang melalui pengerjaan soal. Temuan 36 soal dari 111 soal yang ada merupakan angka yang cukup kecil. Hal ini menunjukkan bahwa kesempatan siswa untuk mengasah daya juang melalui pengerjaan soal berupa masalah matematika masih sangat sedikit.

Temuan muatan karakter berdaya juang pada bagian materi pembelajaran, tagihan kerja dan soal evaluasi merupakan temuan implisit. Artinya, temuan ini tidak secara jelas memperlihatkan implikasi terhadap siswa secara langsung melainkan merupakan muatan potensial yang memfasilitasi siswa dalam mengasah daya juang. Sedangkan, temuan muatan karakter berdaya juang pada bagian non materi merupakan temuan eksplisit. Artinya, temuan ini secara jelas memperlihatkan implikasi terhadap siswa secara langsung melalui kalimat motivasi meskipun tidak ada kata "daya juang" di dalamnya.

Perhatian lebih hendaknya diarahkan kepada muatan karakter berdaya juang pada bagian non materi. Temuan yang didapaTkan pada buku masih memuat karakter berdaya juang secara umum. Temuan ini belum memuat empat aspek daya juang yang lebih rinci yang dikemukakan Stoltz (1997) untuk memotivasi siswa agar mampu mengendalikan kesulitan/masalah, mampu mengakui kesalahan/kekurangan dan bertanggung jawab untuk memperbaikinya, mampu membatasi kesulitan yang ada dan tidak membesarbesarkan masalah, mampu meyakinkan dirinya bahwa kesulitan yang dihadapinya tidak akan abadi dan suatu saat pasti bisa diatasi. Meskipun hal ini mungkin dapat teridentifikasi selama siswa melakukan kegiatan pembelajaran, namun hal ini sulit untuk diidentifikasi di dalam buku kecuali pada kalimat dalam bagian non materi.

\section{KESIMPULAN DAN SARAN}

Berdasarkan hasil penelitian dan pembahasan, dapat dikemukakan beberapa simpulan yakni pada bagian non materi pembelajaran ditemukan 5 kalimat yang mengandung motivasi untuk berdaya juang. Artinya, muatan karakter berdaya juang pada buku hanya memberikan sedikit kalimat motivasi bagi siswa untuk berdaya juang. Pada bagian materi pembelajaran ditemukan 26 masalah sebagai media kegiatan pemecahan masalah untuk mengasah karakter berdaya juang. Artinya, buku memberikan kesempatan untuk mengasah daya juang melalui kegiatan pemecahan masalah.

Pada tagihan kerja ditemukan 4 proyek dan latihan yang mengarahkan pada kegiatan pemecahan masalah, diskusi dan tugas kelompok sebagai kegiatan untuk mengasah karakter berdaya juang. Artinya, buku Tria Utari, Hartono Muatan Karakter... 
Volume 2 Nomor 2, September 2019, ISSN 2599-3291 (Cetak), ISSN 2614-3933 (Online)

memberikan kesempatan untuk mengasah

daya juang melalui kegiatan pemecahan

masalah dan tugas kelompok. Pada soal

evaluasi ditemukan 36 dari 111 soal yang

merupakan masalah matematika sebagai

media untuk mengasah karakter berdaya juang

melalui pengerjaan soal. Artinya, buku

memberikan sedikit kesempatan melalui pengerjaan soal berupa masalah matematika.

\section{DAFTAR PUSTAKA}

Amir, Z \& Risnawati. Psikologi pembelajaran matematika. Yogyakarta: Aswaja Pressindo, 2016.

Bukhari, T. A. S., Saeed, M. M., \& Nisar, M. "The effects of psychological contract breach on various employee level outcomes: The moderating role of Islamic work ethic and adversity quotient". African Journal of Business Management, No.5 (2011): 8393-8398.

Burns, M. About teaching mathematics. Sausalito, CA: Math Solution Publications, 2007.

Cornista, G. A., \& Macasaet, C. J. "Adversity quotient and achievement motivation of selected third year and fourth year psychology students of De La Salle Lipa Ay 2012-2013". Doctoral dissertation, De La Salle Lipa, 2013, diakses pada Juli 2017,

https://www.peaklearning.com/document sl

Devakumar, M \& Thomas, S. "A study of adversity quotient of secondary school students in relation to their academic self concept and achievement motivation". Doctoral dissertation, University of Mumbai, 2012, diakses pada Juli 2017, https://www.peaklearning.com/document sl
Eriyanto. Analisis isi: Pengantar metodologi untuk penelitian ilmu komunikasi dan ilmu-ilmu sosial lainnya. Jakarta: PT Fajar Interpratama Mandiri, 2011

Kripendorff, K. Content analysis: an introduction to its methodology, (2nd ed). Thousand Oaks: Sage Publication, Inc, 2004.

Maureen, M, A. "The level of adversity quotient and social skills of students leaders at De La Salle Lipa". Master Thesis, De La Salle Lipa, 2015, diakses pada Juli 2017 http://www.peaklearning.com/documents/

Menteri Pendidikan dan Kebudayaan. Peraturan Menteri Pendidikan dan Kebudayaan Nomor 21, Tahun 2016, tentang Standar Isi Pendidikan Dasar dan Menengah, 2016.

Menteri Pendidikan Nasional. Peraturan Menteri Pendidikan Nasional RI Nomor 2, Tahun 2008, tentang Buku, 2008.

Napitapulu, L., \& Nashori, H. F. "Pelatihan adversity intellegence untuk meningkatkan kebermaknaan hidup remaja panti asuhan". Jurnal Psikologika No. 23 (Januari 2006)

Parvathy, U. \& Praseeda, M. "Relationship between adversity quotient and academic problem among student teachers". Journal of Humanities and Social Science, No. 19 (2014):23-26.

Phoolka, E. S., \& Kaur, N. Adversity Quotient: A new paradigm to explore. Contemporary Business Studies, No. 3 (2012): 67-78.

Rifameutia, T. Kiat-kiat memantapkan adversity quotient siswa akseleran. Dalam Akbar, $R$ \& Hawadi (Eds.). Akselerasi A-Z informasi program percepatan belajar dan anak berbakat intelektual. Jakarta: PT Gramedia Widiasarana Indonesia,2004.

Savizy, B. "Applicable problems in the history of mathematics: practical examples for the classroom". Teaching mathematics and its applications, No.26 (2007): 45-50

Stoltz, G. P. Adversity quotient: Turning obstacles into opportunities. Kanada: John Wiley \& Sons Inc, 1997. 


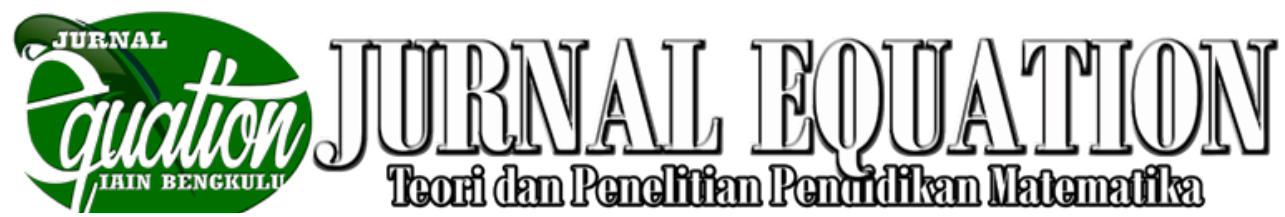

Volume 2 Nomor 2, September 2019, ISSN 2599-3291 (Cetak), ISSN 2614-3933 (Online)

Sudarman. "Adversity quotient: kajian kemungkinan pengintegrasiannya dalam pembelajaran matematika". Aksioma, No.01 (2012): 55-62

Thompson, D.R., Senk, L.S., \& Johnson, G.J. "Oppurtunities to learn reasoning and proof in high school mathematics textbooks". Journal for Researching Mathematics Education, No. 43 (2012): 253-295.

Tigchelaar, L., \& Bekhet. K. E. "The relationship of adversity quotient and personal demographic profile of private business leaders in Egypt". International Journal of Sciences: Basic and Applied Research, No. 20 (2015): 403-422

Zainuddin. "Pentingnya adversity quotient dalam prestasi belajar". Jurnal Guru Membangun, No. 26 (2012) :2 